\title{
Pembuatan masker dan bilik disinfektan sebagai upaya membantu masyarakat terdampak covid-19
}

\section{Imam Safi'i ${ }^{1 *}$, Agata Iwan Candra ${ }^{2}$, Silvi Rushanti Widodo ${ }^{3}$, Ariadi Santoso ${ }^{4}$, Budi Heryanto ${ }^{5}$, Eko Winarti ${ }^{6}$, Afif Nur Rahmadi ${ }^{7}$}

${ }^{1}$ Universitas Kadiri, Kediri, Indonesia, email: imam@unik-kediri.ac.id

${ }^{2}$ Universitas Kadiri, Kediri, Indonesia, email: iwan_candra@unik-kediri.ac.id

${ }^{3}$ Universitas Kadiri, Kediri, Indonesia, email: silvi@unik-kediri.ac.id

${ }^{4}$ Universitas Kadiri, Kediri, Indonesia, email: ariadi_santoso@unik-kediri.ac.id

${ }^{5}$ Universitas Kadiri, Kediri, Indonesia, email: budiheryanto@unik-kediri.ac.id

${ }^{6}$ Universitas Kadiri, Kediri, Indonesia, email: ekowinarti@unik-kediri.ac.id

7Universitas Kadiri, Kediri, Indonesia, email: afifnur@unik-kediri.ac.id

*Koresponden penulis

\section{Info Artikel}

Diajukan: 08 Agst 2020

Diterima: 14 Des 2020

Diterbitkan: 02 Jan 2021

Keywords:

masks; disinfectant

chamber; covid-19

Kata Kunci:

masker; bilik disinfektan; covid-19

Lisensi:

cc-by-sa

\begin{abstract}
The spread of Covid-19 in Indonesia has begun to increase from April 2020, this is because there are still many people who have not implemented the prevention of transmission such as one of them using masks. Observations made at crowded places such as traditional markets found that many people do not use masks due to the scarcity of masks in the market. The methods of making the masks and disinfectant booths aims to help the community, especially in the Kediri region which was affected by the spread of Covid-19. The masks and disinfectant booth products are carried out independently by the Kadiri University in collaboration with the students, lecturers, and alumni of Kadiri University, where the products will be submitted as a form of social service to people in need such as the traditional market in Grogol Village, Kediri Regency. In addition to distributing masks to the public, also given education through socialization the importance of doing a form of prevention of the spread of Covid-19 by always washing hands regularly, keep a distance, and always use a mask.
\end{abstract}

\section{Abstrak}

Penyebaran Covid-19 di Indonesia sudah mulai meningkat dari bulan April 2020, ini dikarenakan masih banyak masyarakat yang belum menerapkan pencegahan penularan seperti salah satunya menggunakan masker. Pengamatan dilakukan pada tempat keramaian seperti pasar tradisional ditemukan masalah masyarakat yang banyak tidak menggunakan masker dikarenakan langkanya masker dipasaran. Pembuatan masker dan bilik disinfektan ini bertujuan untuk membantu masyarakat khususnya di wilayah Kediri yang ikut terdampak penyebaran Covid-19. Metode pembuatan masker dan bilik dilakukan dengan cara memproduksi secara mandiri oleh Universitas Kadiri bekerjasama dengan wirausaha Mahasiswa, Dosen dan Alumni Universitas Kadiri, dimana hasil produk akan diserahkan sebagai bentuk bakti sosial kepada masyarakat yang membutuhkan seperti di pasar tradisional Desa Grogol Kabupaten Kediri. Selain membagikan masker kepada masyarakat, juga diberikan edukaksi melalui sosialisasi pentingnya melakukan bentuk pencegahan penyebaran Covid-19 dengan selalu rutin cuci tangan, jaga jarak dan konsisten selalu menggunakan masker. 


\section{PENDAHULUAN}

Awal Desember 2019 telah terjadi wabah penyakit yang bernama Corona Virus Disease atau disingkat dengan COVID-19. Virus tersebut terjadi pertama kali di Kota Wuhan Provinsi Hubei Cina pada tanggal 20 Januari 2020 yang menyebabkan novel sindrom pernafasan akut parah coronavirus 2 (SARS-Cov-2) (Novel, 2020). Dunia telah mengumumkan bahwa wabah tersebut sebagai Darurat Kesehatan Masyarakat Dunia oleh Organisasi WHO pada tanggal 14 Februari 2020 yang mengkonfirmasi sebanyak 1.381 kematian secara global (AI Farizi \& Harmawan, 2020). Wabah ini diketahui memiliki sifat penyebaran yang sangat cepat, resiko tertular sangat tinggi menyebabkan banyak Pemerintah di semua negara mengambil Langkah pengendalian (Harapan et al., 2020; Lima, 2020).

Indonesia sudah mengalami kondisi dimana kekhawatiran masyarakat terhadap covid-19 cukup besar. Wabah virus ini mulai bulan Maret 2020 masuk melalui beberapa orang yang positif tertular dari luar negeri dan kembali ke Indonesia (Darmawan et al., 2020; Arnani, 2020). Bentuk antisipasi dan pengendalian pencegahan telah diupayakan oleh Pemerintah melalui Satgas Covid-19 seperti pemberlakuakn physical distancing dan beberapa wilayah melakukan isolasi atau lockdown (Yunus \& Rezki, 2020). Bentuk kebijakan pemerintah adalah dengan Pembatasan Sosial Berskala Besar (PSBB) untuk semua wilayah di Indonesia (Safi'i et al., 2020).

Pengendalian lain adalah dengan menerapkan pola hidup sehat dengan sering mencuci tangan dengan sabun, selalu menggunakan masker dan beberapa menerapkan sterilisasi benda maupun anggota tubuh menggunakan cairan disinfektan (Nugroho \& Yulianto, 2020; Budiansyah, 2020). sesuai pemakaiannya dengan alat chamber disinfektan atau bilik sterilisasi (Syandri \& Akbar, 2020). Kebutuhan akan produk tersebut menjadi langka beredar dipasaran dikarenakan perilaku masyarakat yang membeli dengan jumlah yang banyak serta stok yang terbatas, ini membuat harga seperti salah satunya produk masker melambung tinggi. Menurut penelitian yang dilakukan oleh Fatimah (2020) harga masker meningkat sekitar 8-10 kali lipat dari harga normal yaitu 25 ribu per box tergantung dari bahan dan merknya. Ini menyebabkan banyak masyarakat yang akhirnya tidak bisa membeli dan menggunakan masker dengan tujuan untuk mencegah diri terpapar oleh virus Covid-19 (Dewi, 2020).

Universitas Kadiri merupakan Lembaga pendidikan tinggi yang memiliki potensi untuk mengeluarkan kreatititas dan inovasi melalui IPTEKS dengan membuat sebuah produk untuk mencegah penularan wabah virus Covid-19 seperti masker dan bilik disinfektan. Kegunaan produk tersebut bisa untuk membantu masyarakat sekitar di Lingkungan Universitas Kadiri terdampak pandemi Covid-19.

Berdasarkan dari latar belakang diatas, maka permasalahan yang diambil adalah masih banyak masyarakat yang tidak memiliki masker dan belum adanya bilik disinfektan di Kampus Universitas Kadiri. Solusi dari analisis situasi dan permasalahan diatas bisa diwujudkan dengan membuat produk masker 3 lapis yang berbahan kain efektif dalam pencegahan virus 
Covid-19 ini, serta produk bilik disinfektan dengan sistem otomatis menggunakan mikrokontroler dan sensor. Di samping itu terdapat beberapa hasil luaran yang akan ada pada pengabdian ini antara lain:

1. Mendukung Program Peduli Pencegahan Covid-19 pada masyarakat di sekitar wilayah Kediri.

2. Sosialisasi dengan memberikan edukasi pentingnya memakai masker sebagai salah satu pencegahan penularan Covid-19 di masyarakat.

3. Produk Masker dan Bilik Disinfektan.

\section{METODE PELAKSANAAN}

Metode pelaksanaan Pengabdian Kepada Masyarakat (PkM) ini memiliki beberapa tahapan mulai dari persiapan, pelaksanaan dan evaluasi dalam ruang lingkup pembuatan, pembagian dan sosialisasi produk Alat Pelindung Diri (APD) yaitu masker dan bilik atau chamber disinfektan sebagai langkah pencegahan penularan Covid-19 yang terjadi di masyarakat wilayah Kediri Jawa Timur Indonesia. Adapun langkah pelaksanaan sebagai berikut:

\section{Persiapan}

Tim pengabdian masyarakat melakukan rapat dengan Panitia Peduli Pencegahan Covid-19 Universitas Kadiri membahas produk masker dan bilik disinfektan. Kemudian melakukan koordinasi dengan mahasiswa dan alumni Universitas Kadiri yang ikut membantu dalam pembuatan produk. Selanjutnya pembuatan produk dengan cara menyusun konsep produk dan pemilihan konsep produk masker dan bilik disinfektan.

\section{Pelaksanaan}

Pembuatan produk masker yang dilakukan oleh mahasiswa Universitas Kadiri. Masker terbuat dari bahan katun bambu atau kain yang berbahan cotton dan tali elastis. Tahapan pembuatan masker yang pertama adalah melipat kain untuk persiapan potong, kedua adalah menggambar pola masker dikain yang telah dilipat, selanjutnya adalah memotong kain sesuai pola yg telah digambar, tahap keempat adalah menyablon tulisan/ merk masker yang menunjukkan identitas (jika diperlukan), kemudian menjahit masker, dan melakukan packing terhadap produk masker yang sudah jadi.

Sedangkan tahapan pembuatan bilik desinfektan adalah pertama memanaskan solder, selanjutnya menyiapkan pcb lubang ic dan timah, lalu mensolder Arduino pro mini, modul stepdown, relay, dan terminal blok, dioda, transistor dan resistor pada pcb, kemudian atur tegangan modul stepdown ke $5 \mathrm{v}$, lalu hubungkan output $(+)$ dari modul stepdown ke vcc Arduino, selanjutnya hubungkan output (-) dari modul stepdown ke ground Arduino, tahap selanjutnya menghubungkan input (+) dari modul stepdown ke salah satu kaki terminal block sedangkan input (-) modul stepdown dihungkan ke kaki lainnya, kemudian menghubungkan salah satu pin gpio Arduino ke salah satu kaki resistor satu sedangkan kaki lainnya dihubungkan ke basis transistor, dan menghubungkan kaki kolektor transistor ke salah satu pin coil relay sedangkan pin lain terhubung ke $\left(^{+}\right)$input modul step down, langkah berikutnya 
menghubungkan kaki emitor transistor ke (-) input stepdown, lalu menghubungkan salah satu pin gpio Arduino yang belum terpakai ke salah satu kaki resistor dua sedangkan kaki lainnya ke (+) output modul stepdown serta hubungkan pin output dari sensor infrared ke pin ini sedangkan vcc sensor terhubung ke output (+) stepdown dan ground sensor terhubung ke output (-) stepdown, selanjutnya menghubungkan modul pin ISD1820 ke gpio Arduino yang belum terpakai, untuk vcc dan ground dari modul ini terhubung seperti step sebelumnya, lalu menghubungkan salah satu kaki terminal blok yang terhubung ke $(+)$ input modul stepdown ke output (+) dari PSU jaring 12v, sedangkan kaki yang lain terhubung ke output (-) PSU, kemudian menghubungkan kaki com relay ke output (+) PSU dan menghubungkan kaki NO relay ke (+) pompa dc sedangkan (-) pompa terhubung ke (-) PSU. Memasang semua konektor pompa dan membuat program Arduino untuk meng on kan modul suara isd1820 lalu meng on kan relay selama beberapa detik jika dideteksi output high pada sensor infrared, dan meng off kan relay otomatis jika dideteksi output low. Selanjutnya memasang PSU dan rangkaian ke dalam box panel besi supaya aman. Lakukan uji coba, apakah sudah sesuai harapan, jika belum silahkan rombak lagi programnya. Jika sudah bagus dan stabil alat siap diaplikasikan.

Bakti sosial dengan membagikan produk masker dan bilik disinfektan serta sosialisasi mengenai pencegahan covid-19 melalui pemakaian masker, jaga jarak dan sering cuci tangan yang ditujukan kepada masyarakat.

\section{Evaluasi Kegiatan}

Kegiatan pembuatan produk masker dan bilik disinfektan dalam bakti sosial untuk membagikan masker dimasyarakat diperlukan evaluasi terhadap dampak yang melibatkan pemerintah desa dan Ketua Tim Pencegahan Covid-19 di Universitas Kadiri.

\section{HASIL DAN PEMBAHASAN}

Kegiatan persiapan dimulai dengan rapat bersama Tim Pencegahan Covid-19 Universitas Kadiri yang membahas mengenai bahan masker, jumlah lapis masker yang dipakai, dan jumlah kebutuhan produksinya, selain itu juga membahas mengenai produksi bilik disinfektan seperti bahan rangka yang digunakan, sekatnya serta alat penyemprot cairan disinfektan yang digunakan. Pada rapat tersebut juga disepakati mengenai target waktu pengembangan produk sampai selesai produksi.

Selanjutnya pada kegiatan pembuatan produk masker dan bilik disinfektan yang dilakukan bersama mahasiswa dan alumni meliputi pengembangan konsep produk masker dimana beberapa konsep dimunculkan kemudian dipilih konsep produk masker 3 lapis dengan bahan kain bambu dikarenakan kain tersebut lembut, juga efektif menyaring dari virus dan debu. WHO merekomendasikan penggunaan masker kain 3 lapis yang salah satunya bisa terbuat dari bahan katun untuk menyaring virus dan debu serta partikel solid yang lain. Selain itu masker bisa dicuci dan 
digunakan kembali jadi lebih hemat secara biaya. Adapun gambar desain masker seperti gambar dibawah ini.

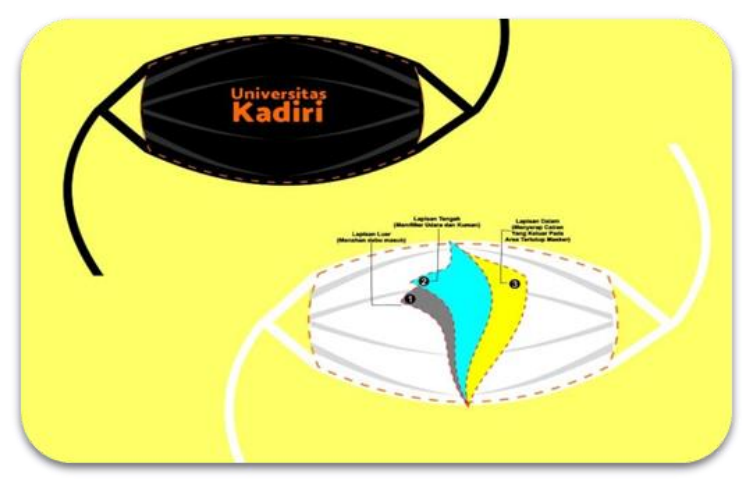

Gambar 1. Desain Produk Masker 3 Lapis

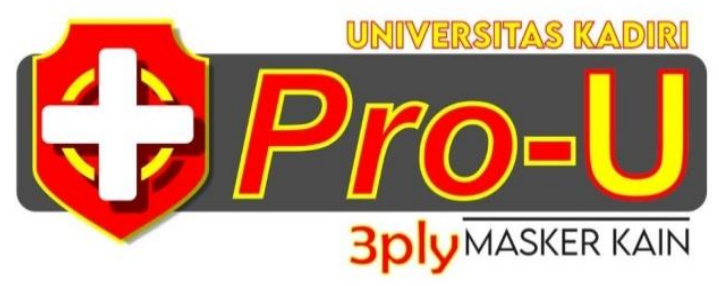

Gambar 2. Desain Kemasan Masker

Sedangkan pada desain konsep yang dipilih produk bilik atau chamber disinfektan dilakukan dengan pemilihan bahan rangka besi hollow $3 \mathrm{~cm} \times 3 \mathrm{~cm}$ dengan tinggi $200 \mathrm{~cm}$ pajang $100 \mathrm{~cm}$ dan lebar $80 \mathrm{~cm}$, sekat bilik dari plastik tebal dan alat penyemprot cairan otomatis dengan menggunakan mikrokontroler sehingga jika ada orang melewati akan terdeteksi secara otomatis akan menyemprotkan cairan disinfektan yang aman untuk tubuh manusia. Adapun hasil desain bilik disinfektan seperti gambar dibawah ini.

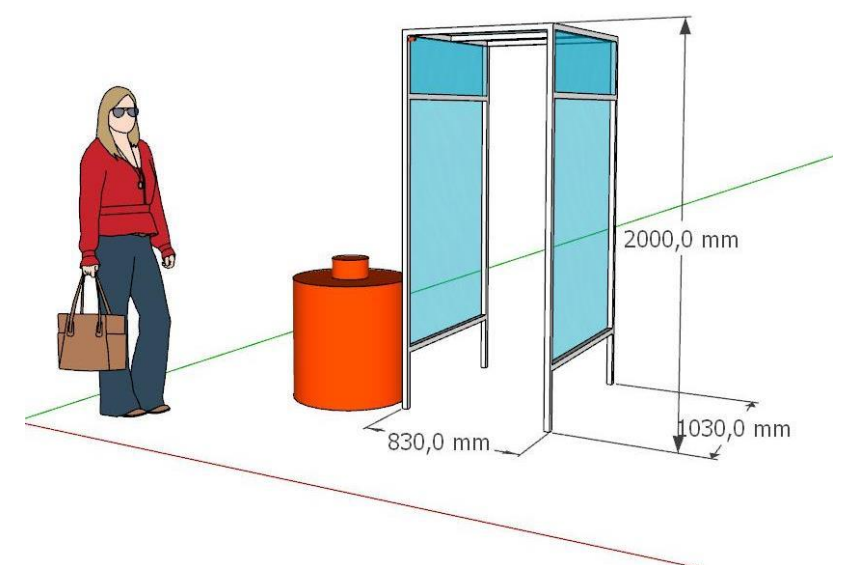

Gambar 3. Desain bilik atau chamber disinfektan 
Setelah desain produk masker dan bilik disinfektan selesai, maka selanjutnya adalah pada tahap pelaksanaan dimana desain tersebut akan diproduksi.

Pada kegiatan pelaksanaan, jumlah produk masker yang telah disepakati pada rapat tim Pencegahan Covid-19 Universitas Kadiri adalah 5000 masker. Dimana dalam memproduksi masker tersebut bekerjasama dengan wirausaha mahasiswa Universitas Kadiri. Untuk bilik disinfektan hanya memproduksi 1 unit yang proses pembuatannya bekerjasama dengan wirausaha Dosen dan Alumni Universitas Kadiri. Proses pelaksanaan produksi berlangsung selama 3 minggu dari bulan pertengahan bulan April sampai dengan pertengahan bulan Mei tahun 2020. Adapun hasil produk masker dan bilik disinfektan seperti gambar dibawah ini.

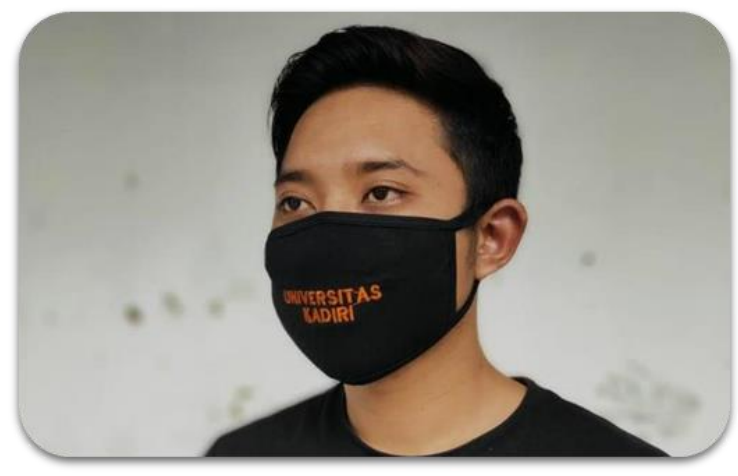

Gambar 4. Hasil Produk Masker Universitas Kadiri

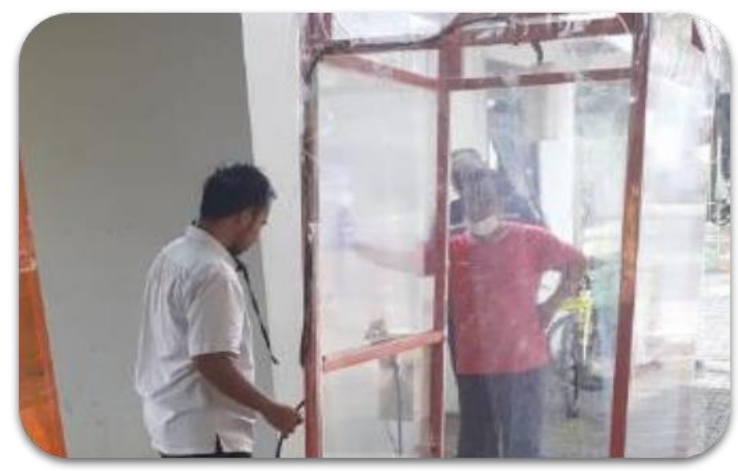

Gambar 5. Hasil produk chamber disinfektan

Produk yang telah dibuat sesuai dengan rencana kemudian akan dilakukan kegiatan bakti sosial bersama tim Pencegahan Covid-19 Universitas Kadiri ke beberapa wilayah di Kediri. Target pembagian masker prioritas pada tempat-tempat dimana banyak orang melakukan aktivitas seperti pasar, ojek online dan beberapa kampung yang dimana kesadaran masyarakatnya terhadap penggunaan masker masih rendah dikarenakan faktor langkanya produk masker dipasaran. 


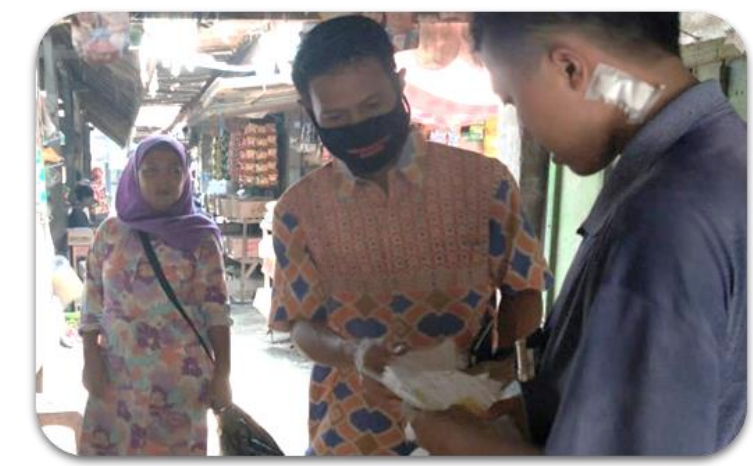

Gambar 6. Pembagian Masker dan sosialisasi di Pasar Tradisional

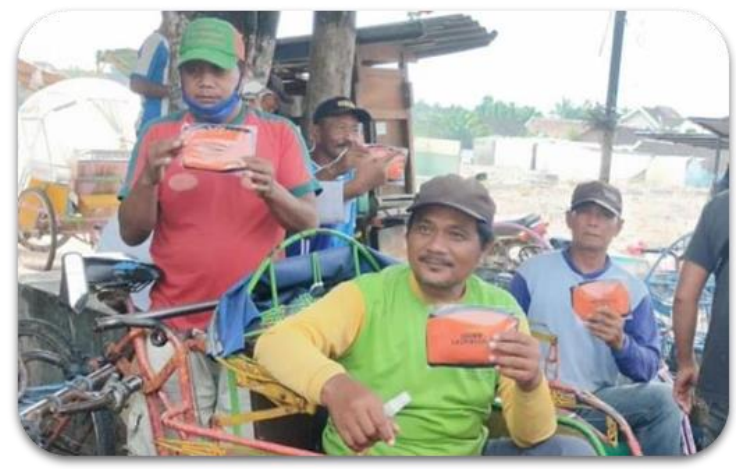

Gambar 7. Beberapa Tukang Becak Menerima Pembagian Masker

Pasar yang dilakukan pembagian masker adalah Pasar Tradisional Grogol yang terletak di Desa Grogol Kecamatan Grogol Kabupaten Kediri. Dimana sebelumnya tim berkoordinasi dengan pihak Kepala Desa Grogol untuk melakukan serah terima bantuan APD serta ijin dalam pembagian masker di pasar tersebut.

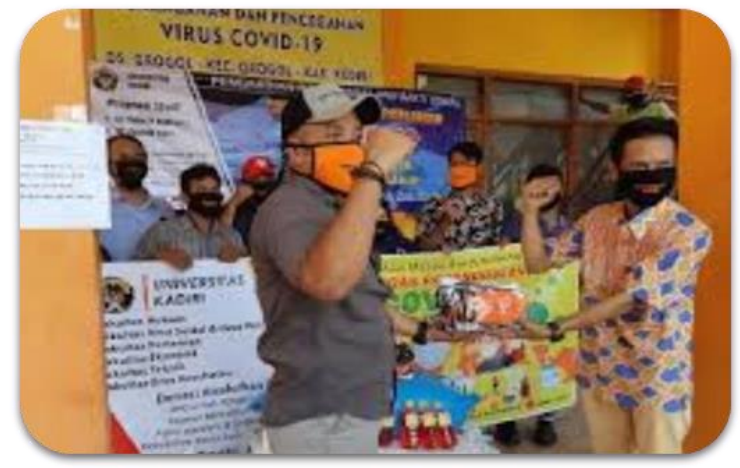

Gambar 8. Penyerahan Produk APD kepada Kepala Desa Grogol

Sedangkan pada hasil produksi bilik disinfektan telah diuji coba dan digunakan di Kampus Universitas Kadiri, dimana Rektor Universitas Kadiri 
telah meresmikan dan ikut mencoba produk bilik disinfektan tersebut dan mengapresiasi produk tersebut dapat bekerja sesuai dengan konsep yang dibuat. Bilik ini berfungsi sebagai salah satu langkah pencegahan dari penyebaran Covid-19.

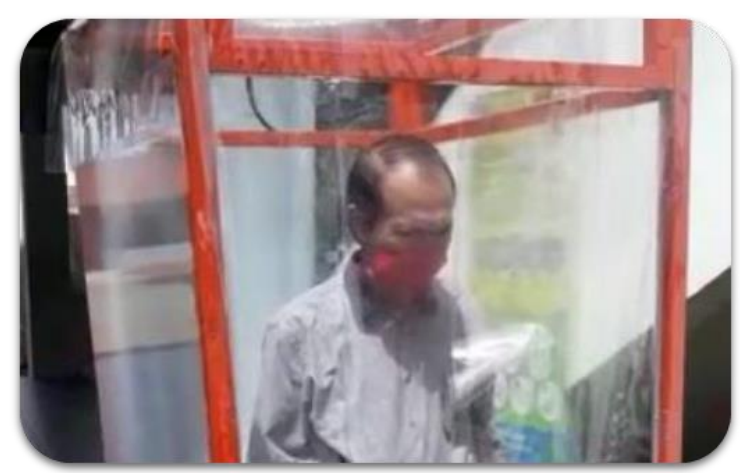

Gambar 9. Rektor Universitas Kadiri mencoba produk bilik disinfektan

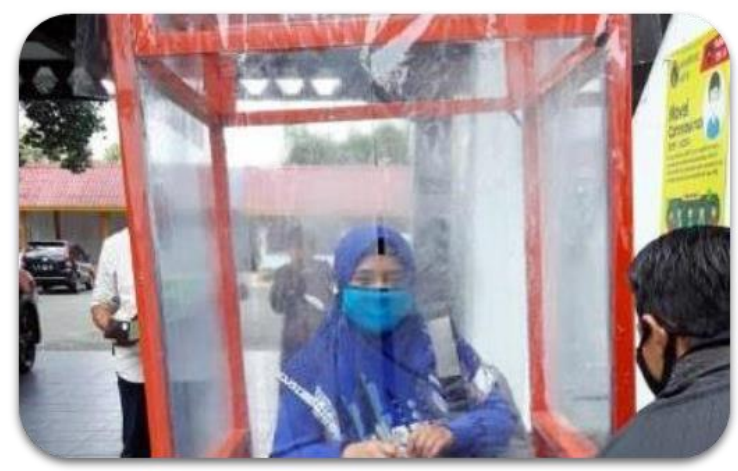

Gambar 10. Dosen di Universitas Kadiri menggunakan bilik disinfektan

Setelah melakukan kegiatan pada tahap persiapan dan pelaksnaan pengabdian kepada masyarakat yang telah dilakukan, maka Tim melakukan evaluasi kegiatan diantaranya adalah laporan hasil kegiatan seperti jumlah masker yang telah dibagikan, respon masyarakat terhadap pembagian masker serta bentuk efektifitas masyarakat dalam konsistensi menggunakan masker disaat beraktivitas.

Dari hasil kegiatan pelaksanaan dilapangan bahwa membagikan masker di tempat seperti pasar sangatlah efektif, karena banyak penjual bahkan pembeli tidak memakai masker. Ini akan berdampak pada cepatnya covid-19 menyebar. Tidak banyaknya yang memakai dikarenakan produk tersebut langka dipasaran dan harganya naik beberapa kali lipat. Maka selain membagikan masker, tim juga memberikan sosialisasi berupa edukasi singkat pentingnya menggunakan masker dalam kegiatan di pasar agar tetap terjaga dari penularan covid-19. 


\section{KESIMPULAN}

Dengan adanya pembuatan masker dan bilik disinfektan dalam upaya pencegahan penyebaran Covid-19 di masyarakat Kediri cukup efektif sesuai dengan tujuan yaitu masyarakat terbantu dan teredukasi tentang pentingnya memakai masker saat beraktivitas. Sedangkan bilik disinfektan berguna untuk mensterilkan orang yang hendak masuk ke dalam kampus Universitas Kadiri dengan penyemprotan disinfektan secara otomatis dengan cairan bahan yang aman bagi tubuh manusia. Civitas akademika dan orang yang hendak masuk ke Universitas Kadiri termasuk bagian dari masyarakat yang dapat menggunakan bilik desinfektan ini.

Saran dalam kegiatan pengabdian kepada masyarakat ini adalah perlunya tinjauan kembali di masyarakat yang telah dikunjungi untuk melihat konsistensi pemakaian masker minimal 2 minggu setelah diadakan kegiatan PkM ini.

\section{UCAPAN TERIMA KASIH}

Ucapan terima kasih bisa disampaikan kepada Universitas Kadiri dan Donasi masyarakat pada Tim Pencegahan Covid-19, dimana telah memberikan dukungan dan pembiayaan terhadap produksi masker dan bilik disinfektan sehingga bisa tersalurkan ke masyarakat yang terdampak pandemi Covid-19.

\section{DAFTAR RUJUKAN}

Al Farizi, S., \& Harmawan, B. N. (2020). Data transparency and information sharing: Coronavirus prevention problems in Indonesia. Jurnal Administrasi Kesehatan Indonesia, 8(2), 35-50. https://doi.org/http://dx.doi.org/10.20473/jaki.v8i2.2020.35-50

Arnani, M. (2020). Timeline Wabah Virus Corona, Terdeteksi pada Desember 2019 hingga Jadi Pandemi Global. Kompas.Com. https://www.kompas.com/tren/read/2020/03/12/113008565/timelinewabah-virus-corona-terdeteksi-pada-desember-2019-hinggajadi?page $=$ all

Budiansyah, A. (2020). Bukan Imbauan, Ini Perintah: Jaga Jarak, Cuci Tangan, Masker! CNBC Indonesia. https://www.cnbcindonesia.com/lifestyle/20200405204309-33-

149896/bukan-imbauan-ini-perintah-jaga-jarak-cuci-tangan-masker

Darmawan, D., Miharja, D., Waluyajati, R. S. R., \& Isnaeniah, E. (2020). Sikap Keberagamaan Masyarakat Menghadapi Wabah COVID-19. Religious: Jurnal Studi Agama-Agama Dan Lintas Budaya, 4(2), 115-124. https://doi.org/https://doi.org/10.15575/rjsalb.v4i2.8596

Dewi, R. S. (2020). Perlindungan Konsumen di Era Pandemi Virus Corona. Yustitiabelen Jurnal Fakultas Hukum Universitas Tulungagung, 6(1), 38-47.

http://journal.unita.ac.id/yustitiabelen/index.php/yustitia/article/view/89

Fatimah, I. R. (2020). Dampak Meningkatnya Harga Masker di Tengah Mewabahnya Covid-19 di Kalangan Masyarakat Ditinjau dari Sudut 
Pandang Tindakan Manusia. OSF Preprints. https://doi.org/https://doi.org/10.31219/osf.io/j5pn9

Harapan, H., Itoh, N., Yufika, A., Winardi, W., Keam, S., Te, H., Megawati, D., Hayati, Z., Wagner, A. L., \& Mudatsir, M. (2020). Coronavirus disease 2019 (COVID-19): A literature review. Journal of Infection and Public Health, 13(5),

667-673.

https://doi.org/https://doi.org/10.1016/j.jiph.2020.03.019

Lima, L. (2020). Virus corona: Lima strategi sukses yang dipakai berbagai negara untuk kendalikan covid-19. BBC News Indonesia. https://www.bbc.com/indonesia/majalah-51974072

Novel, C. P. E. R. E. (2020). The epidemiological characteristics of an outbreak of 2019 novel coronavirus diseases (COVID-19) in China. Zhonghua Liu Xing Bing Xue Za Zhi= Zhonghua Liuxingbingxue Zazhi, 41(2), 145-151. https://doi.org/10.3760/cma.j.issn.02546450.2020.02.003.

Nugroho, I. H., \& Yulianto, D. (2020). Penerapan Disiplin Protokol Kesehatan di Era Kenormalan Baru pada Dunia PAUD. Al-Hikmah: Jurnal Kependidikan Dan Syariah, 8(1), 150-156. http://jurnal.staiba.ac.id/index.php/Al-Hikmah/article/view/166

Safi'i, I., Widodo, S. R., \& Pangastuti, R. L. (2020). Analisis Risiko pada UKM Tahu Takwa Kediri terhadap Dampak Pandemi COVID-19. Jurnal Rekayasa Sistem Industri, 9(2), 107-114. https://doi.org/https://doi.org/10.26593/jrsi.v9i2.4003.107-114

Syandri, S., \& Akbar, F. (2020). Penggunaan Masker Penutup Wajah Saat Salat Sebagai Langkah Pencegahan Wabah Coronavirus Covid-19. SALAM: Jurnal Sosial Dan Budaya Syar-I, 7(3), 261-268. https://doi.org/https://doi.org/10.15408/sjsbs.v7i3.15105

Yunus, N. R., \& Rezki, A. (2020). Kebijakan Pemberlakuan Lock Down Sebagai Antisipasi Penyebaran Corona Virus Covid-19. Salam: Jurnal Sosial Dan Budaya Syar-I, 7(3), 227-238. https://doi.org/https://doi.org/10.15408/sjsbs.v7i3.15083 